\title{
Assessment of Equivalent Radium Activity and Annual Effective Dose Due to Building Materials in Côte D'Ivoire by Gamma Spectrometry: Cases of Cement
}

\author{
Monnehan G. Alain 1,2, Gogon B. D. L. Huberson"1,2, Braffo A. Florentin1, Djagouri Koudou3, \\ Koua A. Antonin ${ }^{1,2}$, Kouakou Omer ${ }^{1 *}$ \\ ${ }^{1}$ Laboratoire de Physique Nucléaire et Radioprotection (LNPR), UFR SSMT, Université Felix Houphouet-Boigny, \\ Abidjan, Côte d'Ivoire \\ ${ }^{2}$ Autorité de Radioprotection, de Sûreté et Sécurité Nucléaires (ARSN), Abidjan, Côte d'Ivoire \\ ${ }^{3}$ Ecole Normal Supérieur, Abidjan, Côte d'Ivoire \\ Email: *ladjuepe@gmail.com
}

How to cite this paper: Alain, M.G., Huberson, G.B.D.L., Florentin, B.A., Koudou, D., Antonin, K.A. and Omer, K. (2019) Assessment of Equivalent Radium Activity and Annual Effective Dose Due to Building Materials in Côte D'Ivoire by Gamma Spectrometry: Cases of Cement. Open Journal of Applied Sciences, 9, 774-783.

https://doi.org/10.4236/ojapps.2019.910063

Received: September 3, 2019

Accepted: October 28, 2019

Published: October 31, 2019

Copyright $\odot 2019$ by author(s) and Scientific Research Publishing Inc. This work is licensed under the Creative Commons Attribution International License (CC BY 4.0).

http://creativecommons.org/licenses/by/4.0/

\section{(c) (i) Open Access}

\begin{abstract}
Radioactivity is a natural phenomenon present in the universe. So, because of human life solidarity with a habitat, we are permanently in contact, especially through building materials. The objective of this work is the determination of the used cement radioactivity level in the buildings in Côte d'Ivoire. Thus, samples of grey and white cement currently used on Ivorian territory were taken. In order to determine the radioactivity level of this cement, samples were analyzed by using gamma spectrometry chain which contains a $\mathrm{NaI}(\mathrm{Tl})$ scintillation detector designed by the German manufacturer LD-DIDACTIC, coupled to a multichannel analyzer (AMC) using a Cassy Lab software. Thus, the specific activity of the primordial radionuclides ${ }^{226} \mathrm{Ra},{ }^{232} \mathrm{Th}$ and ${ }^{40} \mathrm{~K}$, was able to be determined. The average values obtained are $29.66 \mathrm{~Bq} / \mathrm{kg}, 34.88$ $\mathrm{Bq} / \mathrm{kg}$ and $178.424 \mathrm{~Bq} / \mathrm{kg}$ respectively for ${ }^{226} \mathrm{Ra},{ }^{232} \mathrm{Th}$ and ${ }^{40} \mathrm{~K}$. All average values are below the limit values recommended by UNSCEAR. However, we evaluated the radiological parameters such as the equivalent radium activity and the annual effective dose in order to translate the specific activity in terms of harmfulness. Values obtained for these parameters are below those recommended by ICRP and UNSCEAR. These results show that the risk incurred by the use of these different brands of cement is low.
\end{abstract}

\section{Keywords}

Cement, Gamma Spectrometry, Equivalent Radiumactivity, Annual Effective Dose 


\section{Introduction}

Building materials are objects to which we are accustomed and whose radiological impacts could be neglected. Yet these materials are made up of atoms like all existing materials in the universe. In addition, they can have different levels of radioactivity. Building materials cover a wide range of materials, especially from the processing of nature products. But radioactivity is a natural phenomenon that is defined as the spontaneous radiation emission by an atomic nucleus. Therefore, it is present in the raw material that allows the production of cement. However, the exposure to ionizing radiation from building materials is generally low to cause harm to men. But when this exposure exceeds the authorized annual dose this can have health disadvantages. In Côte d'Ivoire, radiological monitoring of materials used in construction is almost non-existent. This suggests a potential danger of exposure of populations to ionizing radiation emitted by elements contained in these materials. It is therefore important to analyze these materials because enormous quantities are used in the construction where we live and spend most of our time. The present work, therefore, highlights the radiological study carried out on cement used in Côte d'Ivoire using gamma spectrometry. Our work consists of two parts. The first part is material and method and the second is results and discussions.

\section{Materials and Methods}

\subsection{Presentation of Samples}

For this current work, we took cement samples from companies whose products are marketed in Côte d'Ivoire. These samples are:

- Sample of CEM II/B 32.5 R (CG1);

- Sample of CEM II/A-L 42.5 N (CB1);

- Sample of CPJ 35 R (CG2);

- Sample of CPJ 32.5 R (CG3);

- Sample of PCJ 32.5 R (CG4).

Samples taken were weighed and sealed during 30 days to reach the secular equilibrium between ${ }^{226} \mathrm{Ra},{ }^{232} \mathrm{Th}$ and their daughters.

\subsection{Materials}

A scintillation counter with a Thalium-doped NaI scintillation crystal (Diameter $38.1 \mathrm{~mm}$ and thickness $50.8 \mathrm{~mm}$ ) [1] has been used. This detector designed by the German manufacturer LD Didactic has a resolution of $662 \mathrm{keV}$ of about $7.5 \%$. In order to constitute a measurement chain, the NaI crystal ( $\mathrm{Tl}$ ) was polarized by a high voltage generator (at $8.5 \mathrm{kV}$ ). At the output of the crystal, the analog signal is converted into a digital signal by the multichannel analyzer (AMC) to be transmitted to the Sensor-Cassy acquisition system. The collected information is carried out to the computer and appears as a spectrum. This equipment is located in the practical room of nuclear physics at the Felix Hou- 
phouet Boigny University of Cocody.

\subsection{Method}

Analysis of the cement samples was performed using gamma spectrometry. However, its implementation requires two essential operations which are: the energy calibration and the determination of the detection efficiency.

Calibration is a tuning process that determines the energy range while eliminating measurement errors. It is, therefore, a prerequisite for any measure. This operation is intended to establish a relationship between the position of the peak in the spectrum and the corresponding $\gamma$ line energy. For this work, a mixed source of americium $\left({ }^{241} \mathrm{Am}\right)$ and cesium $\left({ }^{137} \mathrm{Cs}\right)$ emitting respectively -peaks of energy at $59.54 \mathrm{keV}$ and $661.66 \mathrm{keV}$ have been used. Efficiency reflects the fact that all gamma photons emitted by sources are not detected. Then the detection efficiency noted $\varepsilon$ is the efficiency of the detector used in the chain measurement. In this study, the efficiency curve was obtained using reference materials as sand containing a multi-photon radionuclide which is the ${ }^{226} \mathrm{Ra}$ [2] [3] of $5 \mathrm{kBq}$ activity. After carrying out these operations, we determined the specific activity of the radionuclides like radium $\left({ }^{226} \mathrm{Ra}\right)$, thorium $\left({ }^{232} \mathrm{Th}\right)$ and potassium $\left({ }^{40} \mathrm{~K}\right) .{ }^{226} \mathrm{Ra}$ was measured using the ${ }^{214} \mathrm{~Pb}$ peak $(351.93$ $\mathrm{keV})$ and the ${ }^{214} \mathrm{Bi}$ line $(609.31 \mathrm{keV})[2]$. For ${ }^{232} \mathrm{Th}$ quantification, we used the ${ }^{212} \mathrm{~Pb}(238.63 \mathrm{keV})$ line and the ${ }^{228} \mathrm{Ac}(911.20 \mathrm{keV})$ line. For the ${ }^{40} \mathrm{~K}$, it was determined using its line emitted at $1460.83 \mathrm{keV}$. From these specific activities measured, we have been able to achieve the quantities that are the Equivalent Radium Activity and the Annual Effective Dose using the mathematical relationship below:

- The Equivalent Radium Activity noted $R a_{e q}$

$$
R a_{e q}=A_{R a}+1.43 A_{T h}+0.077 A_{K}\left(\mathrm{~Bq} \cdot \mathrm{kg}^{-1}\right) \quad \text { [4] }
$$

$A_{R a}, A_{T h}$ and $A_{K}$ are the specific activities of ${ }^{226} \mathrm{Ra},{ }^{232} \mathrm{Th}$ and ${ }^{40} \mathrm{~K}$ respectively.

- The Annual Effective Dose noted $H_{R}\left(\mathrm{mSv} \cdot \mathrm{year}^{-1}\right)$ :

$$
H_{R}=D\left(\mathrm{nGy} \cdot \mathrm{h}^{-1}\right) \times 8760(h) \times 0.8 \times 0.7\left(\mathrm{~Sv} \cdot \mathrm{Gy}^{-1}\right) \times 10^{-3}
$$

with $D\left(\mathrm{nGy} \cdot \mathrm{h}^{-1}\right)=0.92 A_{R a}+1.1 A_{T h}+0.08 A_{K}$;

$D$ : is the absorbed dose rate given by UNSCEAR and EC;

$8760 \mathrm{~h}$ : is the number of hours in a year;

0.8 : is the weighting factor that implies that $80 \%$ of the time is spent inside a build in;

0.7: represents the conversion factor from an absorbed dose to an effective dose.

\section{Results and Discussions}

\subsection{Specific Activity of ${ }^{226} \mathrm{Ra},{ }^{232} \mathrm{Th}$ and ${ }^{40} \mathrm{~K}$}

In the present work the specific activity of ${ }^{226} \mathrm{Ra},{ }^{232} \mathrm{Th}$ and ${ }^{40} \mathrm{~K}$ radionuclides 
have been determined. This choice is mainly motivated by the fact that these three radionuclides are naturally present in the Earth's crust. Therefore, these radionuclides are also found in the cement whose basic constituents are clay and limestone. The concentrations of these radionuclides are shown in Figure 1.

The values of the specific activities presented in Table 1 are below the limit values recommended by the United Nations Scientific Committee on the Effects of Atomic Radiation (UNSCEAR) [4]. These limit values for building materials are $50 \mathrm{~Bq} \cdot \mathrm{kg}^{-1}$ for ${ }^{226} \mathrm{Ra}$ and ${ }^{232} \mathrm{Th}$, and $500 \mathrm{~Bq} \cdot \mathrm{kg}^{-1}$ for ${ }^{40} \mathrm{~K}$. The specific activity values of ${ }^{226} \mathrm{Ra}$ range from $18.85 \pm 1.68 \mathrm{~Bq} \cdot \mathrm{kg}^{-1}$ to $50.60 \pm 2.26$ $\mathrm{Bq} \cdot \mathrm{kg}^{-1}$ with an average of $29.66 \mathrm{~Bq} \cdot \mathrm{kg}^{-1}$. The specific activities of other radioelements vary respectively from $22.94 \pm 1.96 \mathrm{~Bq} \cdot \mathrm{kg}^{-1}$ to $41.82 \pm 3.54 \mathrm{~Bq} \cdot \mathrm{kg}^{-1}$ for ${ }^{232} \mathrm{Th}$ with an average of $34.88 \mathrm{~Bq} \cdot \mathrm{kg}^{-1}$, and from $111.10 \pm 7.03 \mathrm{~Bq} \cdot \mathrm{kg}^{-1}$ to $309.74 \pm 19.59 \mathrm{~Bq} \cdot \mathrm{kg}^{-1}$ for the ${ }^{40} \mathrm{~K}$ with an average of $178.424 \mathrm{~Bq} \cdot \mathrm{kg}^{-1}$. The specific activities of radionuclides are generally lower in CB1 white cement than grey cement samples (except for ${ }^{40} \mathrm{~K}$ potassium where the minimum value corresponds to CG4 cement). This finding could be explained by the fact that white cement consists essentially of pure chalk and white clay (sedimentary rocks). While the grey cement contains pozzolana (volcanic rock). In fact, the natural radioactivity of soils and rocks is due to the presence of three long-lived natural radioelements: ${ }^{238} \mathrm{U},{ }^{232} \mathrm{Th},{ }^{40} \mathrm{~K}$ and their daughters such as radium $\left({ }^{226} \mathrm{Ra}\right)$, which have a higher content in volcanic rocks (igneous rocks) than in sedimentary rocks.

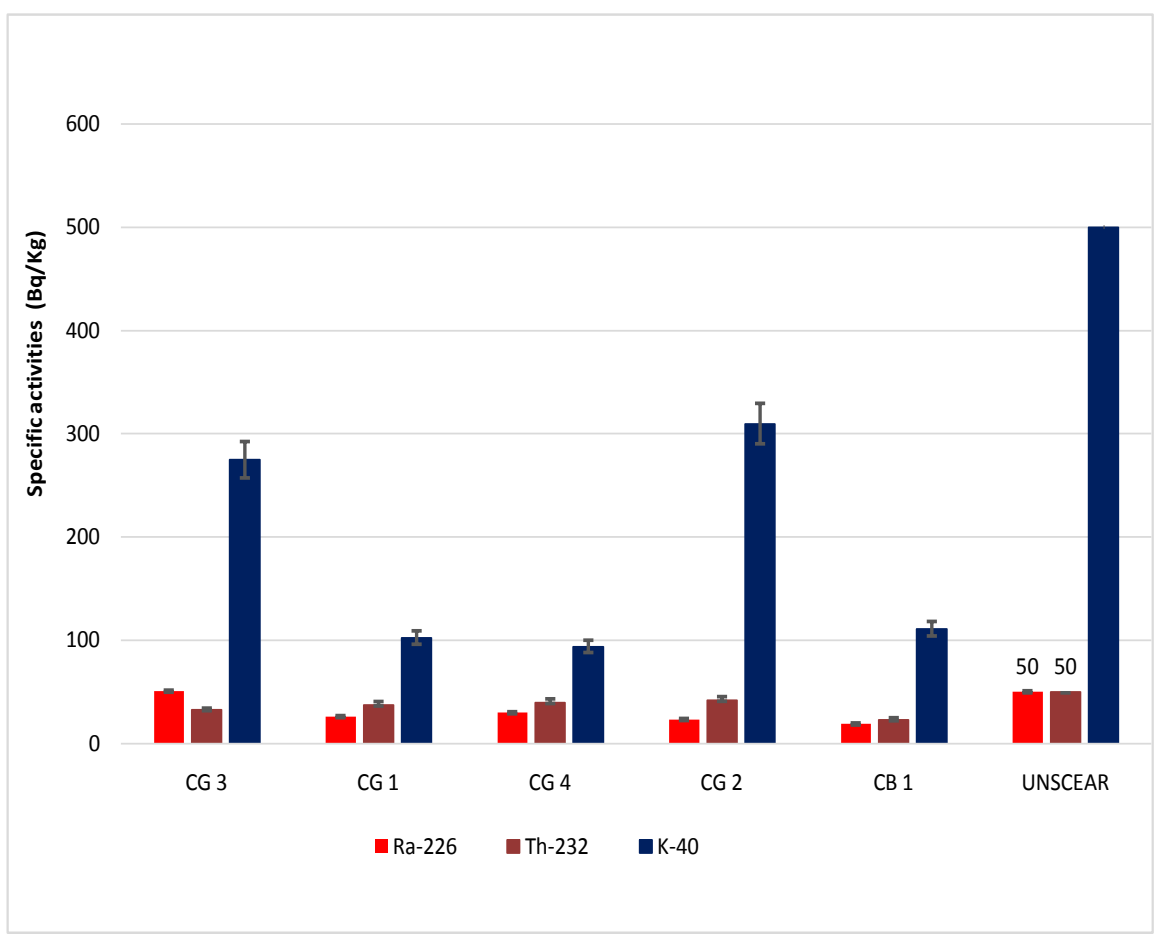

Figure 1. Comparison of specific activities of ${ }^{226} \mathrm{Ra},{ }^{232} \mathrm{Th}$ and ${ }^{40} \mathrm{~K}$ in the samples. 
Table 1. Comparison of specific activities of ${ }^{226} \mathrm{Ra},{ }^{232} \mathrm{Th}$ and ${ }^{40} \mathrm{~K}$ in the samples.

\begin{tabular}{ccccc}
\hline & Type & $\mathbf{A}_{\mathrm{Ra}}(\mathrm{Bq} / \mathrm{kg})$ & $\mathbf{A}_{\mathrm{Th}}(\mathrm{Bq} / \mathrm{kg})$ & $\mathbf{A}_{\mathrm{K}}(\mathrm{Bq} / \mathrm{kg})$ \\
\hline CG 4 & Grey & $29.72 \pm 2.65$ & $39.64 \pm 3.54$ & $94.00 \pm 5.95$ \\
CG 3 & Grey & $50.60 \pm 2.26$ & $32.74 \pm 1.46$ & $274.73 \pm 17.628$ \\
CG 2 & Grey & $23.19 \pm 2.07$ & $41.82 \pm 3.54$ & $309.74 \pm 19.59$ \\
CB 1 & White & $18.85 \pm 1.68$ & $22.94 \pm 1.96$ & $111.10 \pm 7.03$ \\
CG 1 & Grey & $25.96 \pm 2.30$ & $37.28 \pm 3.33$ & $102.55 \pm 6.50$ \\
UNSCEAR & -- & 50 & 50 & 500 \\
\hline
\end{tabular}

\subsection{Equivalent Radium Activity Ra}

Equivalent radium activity was introduced to evaluate the radiation risks from ${ }^{226} \mathrm{Ra},{ }^{232} \mathrm{Th}$ and ${ }^{40} \mathrm{~K}$ radionuclides in building materials. It is the most widely used index for radiological risk assessment and can be calculated using Equation 1 proposed by Beretka and Mathew [4]. It is a weighted sum of specific activities based on the assumption that $370 \mathrm{~Bq} \cdot \mathrm{kg}^{-1}$ of ${ }^{226} \mathrm{Ra}, 259 \mathrm{~Bq} \cdot \mathrm{kg}^{-1}$ of ${ }^{232} \mathrm{Th}$ and 4810 $\mathrm{Bq} \cdot \mathrm{kg}^{-1}$ of ${ }^{40} \mathrm{~K}$ produce the same gamma radiation dose rate [4]. Any building material whose equivalent radium activity exceeds $370 \mathrm{~Bq} \cdot \mathrm{kg}^{-1}$ is not recommended and is considered as an unhealthy material [4]. The values of this factor are indicated and compared to the UNSCEAR [5] limit value of $370 \mathrm{~Bq} \cdot \mathrm{kg}^{-1}$ in Figure 2 and Table 2.

The equivalent radium activity ranges from $60.21 \pm 5.02 \mathrm{~Bq} \cdot \mathrm{kg}^{-1}$ to $118.57 \pm$ $5.70 \mathrm{~Bq} \cdot \mathrm{kg}^{-1}$ with $93.28 \mathrm{~Bq} \cdot \mathrm{kg}^{-1}$ average. These values are well below the value recommended by UNSCEAR ( $\left.370 \mathrm{~Bq} \cdot \mathrm{kg}^{-1}\right)$. The values of equivalent radium activity were also compared to those obtained in other studies conducted in some countries as shown in Figure 3 and Table 3.

The average equivalent radium activity for grey cement samples (101.55, in this work) is lower than that obtained in Algeria, Australia and India. But this activity is higher than those obtained in Lebanon, Tunisia, Ghana and Nigeria. Regarding white cement, the equivalent radium activity is higher than that measured in Tunisia and lower than that of Cuba and Lebanon.

\subsection{Annual Effective Dose $H_{R}$}

The effective dose is a protection quantity expressed in millisievert (mSv). It allows taking into account for an individual the effect of ionizing radiation on the whole organism from equivalent doses weighted in all tissues and organs of the body. The annual effective dose noted $\mathrm{H}_{\mathrm{R}}\left(\mathrm{mSv} \cdot \mathrm{year}^{-1}\right)$ is defined from this quantity. It is evaluated by equation 2 given by the European Commission (EC) and the United Nations Scientific Committee on the Effects of Atomic Radiation (UNSEAR) [11]. For this quantity, the limit value recommended by the ICRP is $1 \mathrm{mSv} \cdot \mathrm{year}^{-1}$ for the public.

Measurements on cement samples yielded annual effective dose values 
ranging from $0.252 \pm 0.021 \mathrm{mSv} \cdot$ year $^{-1}$ to $0.513 \pm 0.021 \mathrm{mSv} \cdot \mathrm{year}^{-1}$ with 0.427 $\mathrm{mSv} /$ year average. We also note that grey cement values remain the lowest. Table 4 and Figure 4 illustrate these results.

These values are below the limit value set at $1 \mathrm{mSv} /$ year by the ICRP (Table 5 and Figure 5).

It is noted that the annual effective dose for grey cement samples $(0.427$ in this work) is higher than that obtained in Ghana, Tunisia and Egypt. But this dose is lower than that obtained in Turkey. For white cement, the annual effective dose is roughly equal to that measured in Tunisia and Ghana.

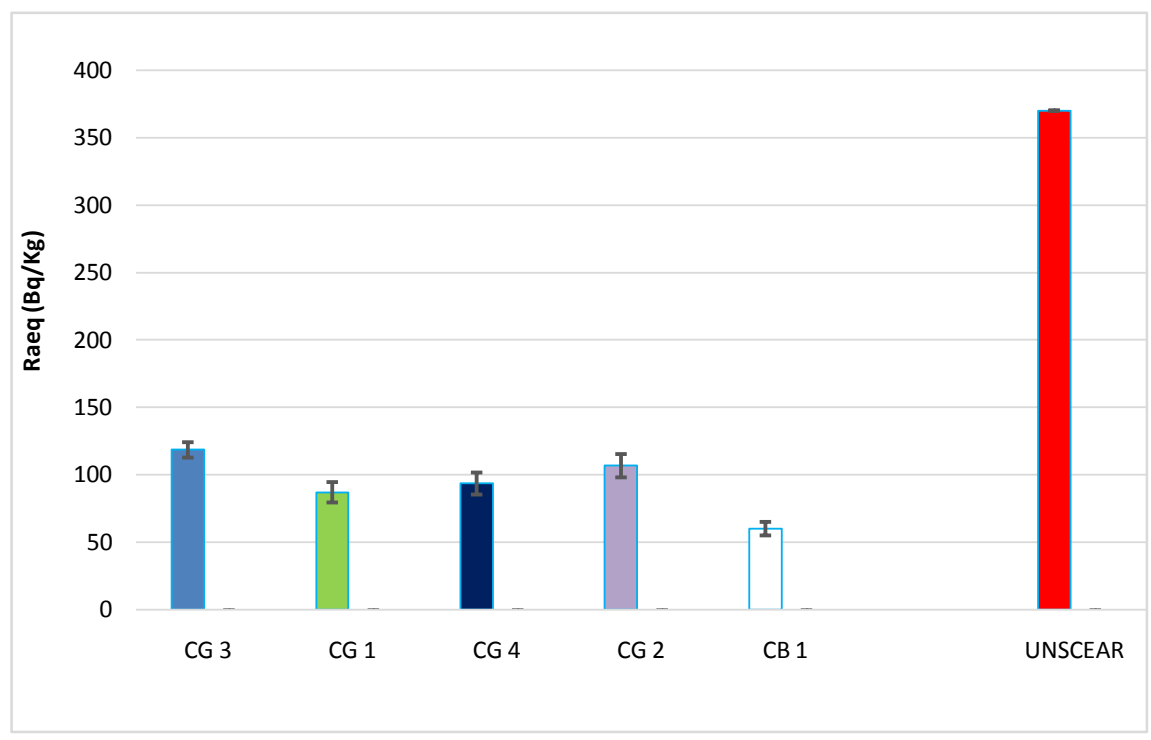

Figure 2. Comparison of equivalent radium activity (Raeq).

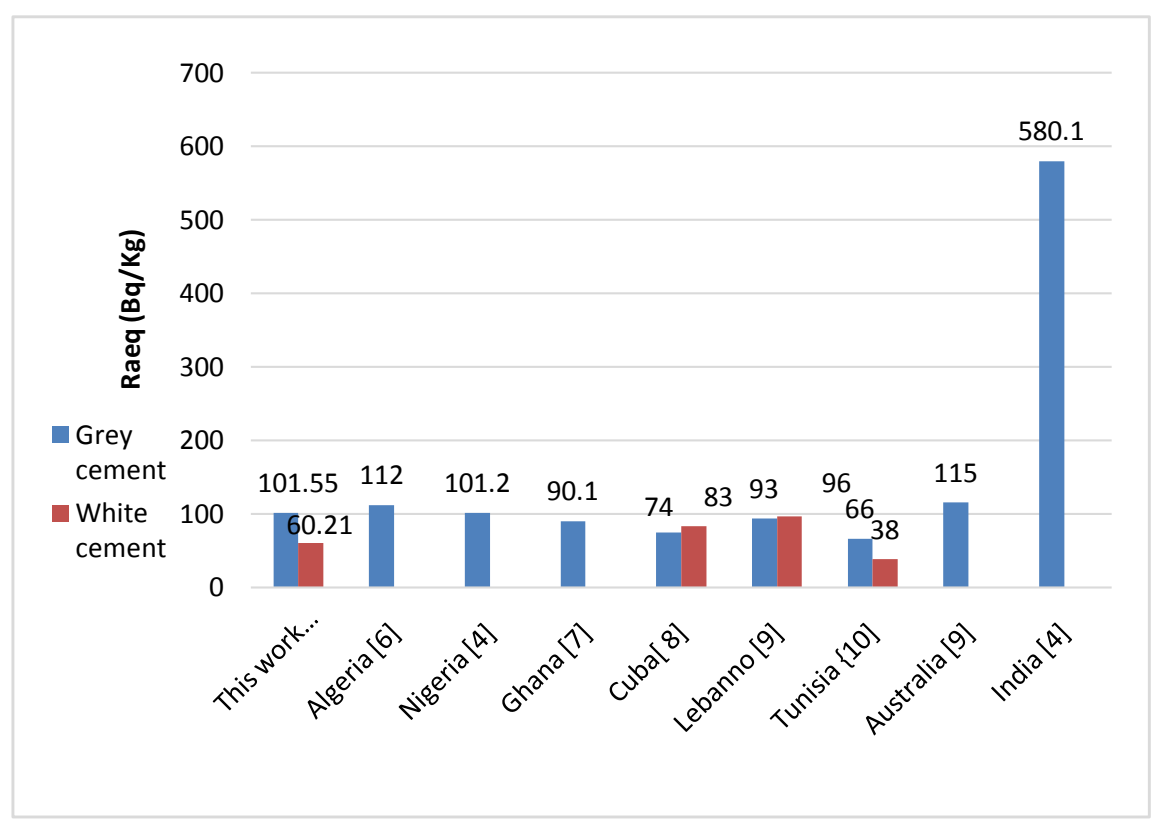

Figure 3. Comparison of equivalent radium activity with other countries' studies. 
Table 2. Comparison of equivalent radium activity.

\begin{tabular}{ccc}
\hline Samples & Type & $\mathrm{Ra}_{\mathrm{eq}}(\mathrm{Bq} / \mathrm{kg})$ \\
\hline CG 4 & Grey & $93.64 \pm 8.17$ \\
CG 3 & Grey & $118.57 \pm 5.70$ \\
CG 2 & Grey & $106.84 \pm 8.64$ \\
CB 1 & White & $60.21 \pm 5.02$ \\
CG 1 & Grey & $87.16 \pm 7.56$ \\
UNSCEAR & & 370 \\
\hline
\end{tabular}

Table 3. Comparison of equivalent radium activity with other countries' studies.

\begin{tabular}{|c|c|c|}
\hline Countries & $\mathrm{Ra}_{\mathrm{eq}}\left(\mathrm{Bq} \cdot \mathrm{kg}^{-1}\right)$ & References \\
\hline Algeria & 112 & Amrani D. et Tahtat M. (2001) [6] \\
\hline Nigeria & 101.2 & Olarinoye, I. Oyeleke (2013) [4] \\
\hline Ghana & 90.1 & Kpeglo et al., (2011) [7] \\
\hline Cuba & $74^{*} ; 83^{* *}$ & Brigido Flores O. et col(2008) [8] \\
\hline Lebanon & $93^{*} ; 96^{* *}$ & Kobeissi M. A. et $\operatorname{col}(2008)$ [9] \\
\hline Tunisia & $66^{*} ; 38^{* *}$ & FatenTurqui (2010) [10] \\
\hline Australia & 115 & Kobeissi M. A. et $\operatorname{col}(2008)$ [9] \\
\hline India & 580.1 & Olarinoye, I. Oyeleke et al. (2013) [4] \\
\hline Cote d'Ivoire & $87.16^{*}-118.57^{*}(101.55)^{*} 60.21^{* *}$ & This work \\
\hline
\end{tabular}

${ }^{*}$ Grey cement; ${ }^{*}$ White cement; ( ) Average.

Table 4. Comparison of annual effective dose.

\begin{tabular}{ccc}
\hline Samples & Type & $\mathrm{H}_{\mathrm{R}}(\mathrm{mSv} / \mathrm{year})$ \\
\hline CG 4 & Grey & $0.385 \pm 0.033$ \\
CG 3 & Grey & $0.513 \pm 0.021$ \\
CG 2 & Grey & $0.451 \pm 0.036$ \\
CB1 & White & $0.252 \pm 0.021$ \\
CG 1 & Grey & $0.358 \pm 0.031$ \\
CIPR & -- & 1 \\
\hline
\end{tabular}

Table 5. Comparison of $H_{R}$ values with other studies results.

\begin{tabular}{ccc}
\hline Countries & $\mathrm{H}_{\mathrm{R}}\left(\mathrm{mSv} \cdot \mathrm{an}^{-1}\right)$ & References \\
\hline Turkey & $0.5^{*} ; 0.3^{* *}$ & Turhan S et al. (2008) [12] \\
Ghana & $(0.21)^{*}$ & Kpeglo et al., (2011) [7] \\
Tunisia & $(0.27)^{*} ; 0.16^{* *}$ & Faten Turqui (2010) [10] \\
Egypt & 0.09 & El Alfifi M.E. et al. $[13]$ \\
Cote d'Ivoire & $0.358^{*}-0.513^{*}(0.427)^{*} 0.252^{* *}$ & This work
\end{tabular}

${ }^{\star}$ Grey cement; ${ }^{* *}$ White ciment; ( ) Average. 


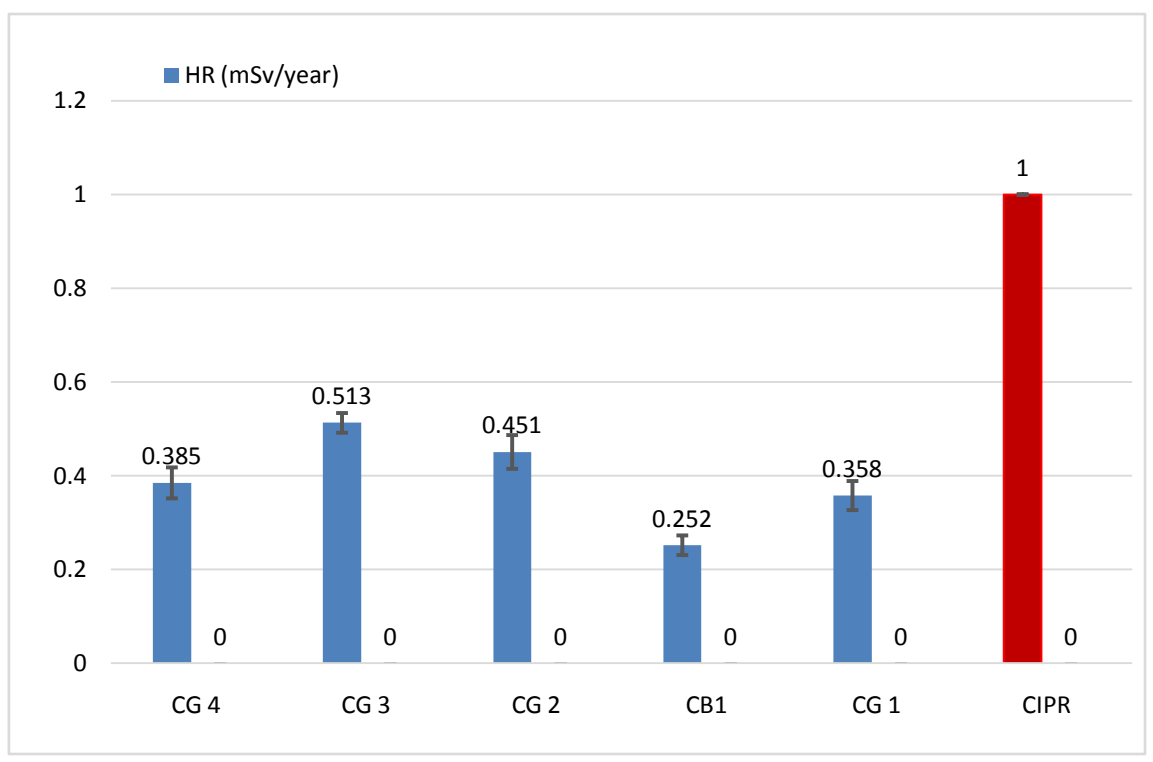

Figure 4. Comparison of annual effective dose.

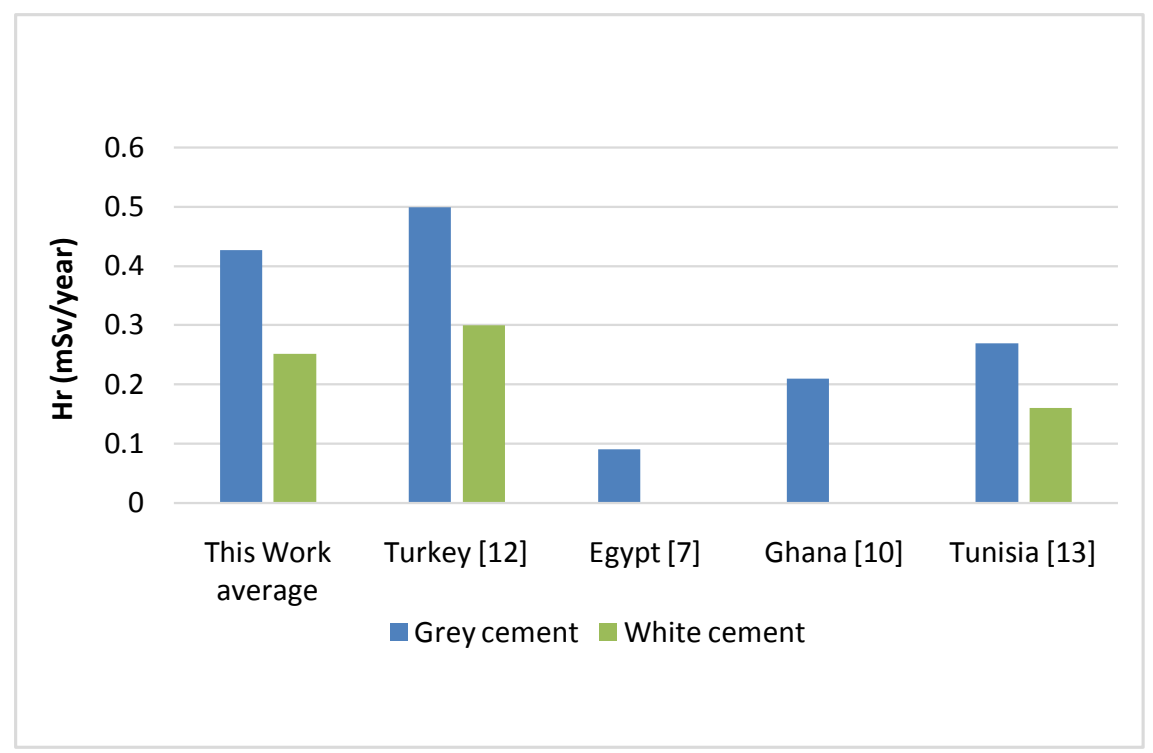

Figure 5. Comparison of $\mathrm{H}_{\mathrm{R}}$ values with other studies results.

\section{Conclusion}

The present work is devoted to the determination of radioactivity levels of the building material that is cement. The study was carried out on the grey cement samples of various companies very present in the construction and the white cement of one company. The purpose is to evaluate the radioactivity of these samples. So samples were sealed in polyethylene packaging to prevent contamination during 30 days in order to reach secular equilibrium. Then they brought into contact with the German manufacturer LD-DIDACTIC scintillation counter for analysis. The analysis of the samples made it possible to determine the specific activities whose average values are $29.66 \mathrm{~Bq} \cdot \mathrm{kg}^{-1}$ for the ${ }^{226} \mathrm{Ra} ; 34.88$ 
$\mathrm{Bq} \cdot \mathrm{kg}^{-1}$ for the ${ }^{232} \mathrm{Th} ; 178,424 \mathrm{~Bq} \cdot \mathrm{kg}^{-1}$ for the ${ }^{40} \mathrm{~K}$. These average values are all below the limit values recommended by UNSCEAR. From these specific activities, we carried out the radiological study by determining the quantities that are the equivalent radium activity $\mathrm{Ra}_{\mathrm{eq}}$ and the annual effective dose $H_{R}$. The average values for each of these parameters are well below the values recommended by UNSCEAR, the ICRP and below the averages measured in some countries. This means that the radiological risk (relative to the unit of mass) incurred by the populations is low. In addition, it appears generally that white cement is less radioactive than grey cement. However, it would be appropriate to increase the number of white cement samples. So that it will be representative and we can confirm or deny the finding report. In perspective we plan to increase the number of samples and extend this study to other building materials such as sand, gravel, plaster.

\section{Conflicts of Interest}

The authors declare no conflicts of interest regarding the publication of this paper.

\section{References}

[1] Schlenkhoff, P. and Sommer, K. (2012) Manuel d'utilisationLeybold 559901, Lehr-und Didaktiksteme, LD Didactic Gmbh.

[2] Bé, M., et al. (2008) Liste des émissions X et gamma: Nucléide-LARA Bibliothèque des émissions alpha, $\mathrm{X}$ et gamma. Commissariat de l'Energie Atomique, France, 25-212.

[3] Institut de Radioprotection et de Sureté Nucléaire et Institut National de Recherche et de Sécurité (2014) Radionucléides: Radium-226, mars 2014. Radioprotection D4318, France.

[4] Oyeleke, I.O., et al. (2014) Gamma Spectrometric Analysis of Different Brands of Cement Used in NIGERIA. South Pacific Journal of Technology and Science, 1, 102-109.

[5] United Nations Scientific Committee on the Effect of Atomic Radiation (UNSCEAR) (2000) Source and Effects of Ionizing Radiation: Exposures from Natural Radiation Sources. New-York, 83-156. https://doi.org/10.18356/fa7a3c47-en

[6] Amrani, D. and Tahtat, M. (2001) Natural Radioactivity in Algerian Buildings Materials. Applied Radiation and Isotopes, 54, 687-689.

https://doi.org/10.1016/S0969-8043(00)00304-3

[7] Kpeglo, D.O., et al. (2011) Natural Radioactivity and Its Associated Radiological Hazards in Ghanaian Cement. Research Journal of Environmental and Earth Sciences, 3, 160-166.

[8] Brigido Flores, O., Montalván Estrada, A., Rosa Suárez, R., Tomás Zerquera, J. and Hernández Pérez, A. (2008) Natural Radionuclide Content in Buildings and Gamma Dose Rate in Dwellings in Cuba. Journal of Environmental Radioactivity, 99, 1834-1837. https://doi.org/10.1016/j.jenvrad.2008.08.001

[9] Kobeissi, M.A., et al. (2008) Natural Radioactivity Measurements in Buildings Materials in Southern Lebanon. Journal of Environmental Radioactivity, 99, 1279-1288. https://doi.org/10.1016/j.jenvrad.2008.03.007 
[10] Turqui, F. (2010) Détermination de la Radioactivité naturelle dans les matériaux de constructions par spectrométrie gamma, projet de fin d'étude, université du 7 novembre, Carthage, Tunisie.

[11] Arman, E. (2005) An Investigation on the Natural Radioactivity of Building Materials, Raw Materials and Interior Coatings in Central Turkey. Turkish Journal of Medical Sciences, 37, 199-203.

[12] Tuhran, S., et al. (2008) Assessment of Natural Radioactivity and Radiological Hazards in Turkish Cement and Its Raws Materials. Journal of Radiological Protection, 28, 83-91.

[13] El Afifi, E.M., Khalifa, S.M. and Aly, H.F. (2006) Evaluation of U, Th et K and Emanated Radon in Some NORM and TENORM Samples. Radiation Measurements, 41, 621-633. https://doi.org/10.1016/j.radmeas.2005.09.014 